\title{
Interleukin-5 in the Pathophysiology of Severe Asthma
}

\author{
Corrado Pelaia', Giovanni Paoletti ${ }^{2,3}$, Francesca Puggioni ${ }^{2,3}$, Francesca Racca ${ }^{2,3}$, \\ Girolamo Pelaia', Giorgio Walter Canonica ${ }^{2,3}$ and Enrico Heffler ${ }^{2,3 *}$ \\ ${ }^{1}$ Department of Medical and Surgical Sciences, University "Magna Græcia" of Catanzaro, Catanzaro, Italy, ${ }^{2}$ Department of \\ Biomedical Sciences, Humanitas University, Pieve Emanuele, Italy, ${ }^{3}$ Personalized Medicine, Asthma and Allergy, Humanitas \\ Clinical and Research Center, IRCCS, Rozzano, Italy
}

Interleukin-5 (IL-5) exerts a central pathogenic role in differentiation, recruitment, survival, and degranulation of eosinophils. Indeed, during the last years, significant advances have been made in our understanding of the cellular and molecular mechanisms underlying the powerful actions of IL-5 finalized to the induction, maintenance, and amplification of eosinophilic inflammation. Therefore, IL-5 is a suitable target for add-on biological therapies based on either IL-5 inhibition (mepolizumab, reslizumab) or blockade of its receptor (benralizumab). These modern treatments can result in being definitely beneficial for

OPEN ACCESS

Edited by:

Felice Rivellese,

Queen Mary University of London, United Kingdom

Reviewed by: Janos Paloczi, National Institutes of Health $(\mathrm{NIH})$, United States Mario Sanchez-Borges, El Ávila Clinic, Venezuela

*Correspondence: Enrico Heffler enrico.heffler@hunimed.eu; heffler.enrico@gmail.com

Specialty section:

This article was submitted to Clinical and Translational Physiology, a section of the journal Frontiers in Physiology

Received: 01 October 2019 Accepted: 02 December 2019 Published: 17 December 2019

Citation:

Pelaia C, Paoletti G, Puggioni F, Racca F, Pelaia G, Canonica GW and Heffler E (2019) Interleukin-5 in the Pathophysiology of Severe Asthma.

Front. Physiol. 10:1514. doi: 10.3389/fphys.2019.01514 patients with severe type 2 (T2)-high eosinophilic asthma, refractory to conventional antiinflammatory drugs such as inhaled and even systemic corticosteroids.

Keywords: IL-5, eosinophils, T2-high asthma, mepolizumab, reslizumab, benralizumab

\section{INTRODUCTION}

Asthma is a chronic and heterogeneous airway disorder, characterized by recurrent respiratory symptoms including wheezing, cough, and chest tightness, which are caused by usually reversible airflow limitation due to bronchial inflammation and remodeling (Holgate et al., 2015; Pelaia et al., 2015). In particular, many patients with severe asthma express a type 2 (T2)-high phenotype featured by eosinophilic inflammation (Bousquet et al., 1990; Schleich et al., 2014). Indeed, airway eosinophilic infiltration is quite frequent in both allergic and non-allergic asthma, and can also occur in severe and fatal disease (Huber and Koessler, 1922; Houston et al., 1953; Varricchi et al., 2016; Haldar, 2017). T2-high asthma is characterized by accumulation of eosinophils within the airways, where these cells produce and release cytokines, chemokines, growth factors, cytotoxic proteins, and lipid mediators, which together play a relevant role in the pathobiology of bronchial inflammation and remodeling (Bochner and Gleich, 2010). Detection of high eosinophil counts in both peripheral blood and induced sputum is a common feature of T2-high asthma. In this regard, it is noteworthy that airway eosinophilia can occur in more than half asthmatic subjects, and high eosinophil levels are associated with recurrent asthma exacerbations and severe bronchial obstruction (Bousquet et al., 1990).

The most important biological factor responsible for eosinophil differentiation, growth, activation, survival, and recruitment to airways is interleukin-5 (IL-5) (Stirling et al., 2001; Fulkerson and Rothenberg, 2013; Varricchi and Canonica, 2016). Therefore, this cytokine exerts key functions in the pathogenesis of eosinophilic asthma, which is often therapeutically responsive to corticosteroids because of its effective ability to induce eosinophil apoptosis (Zhang et al., 2000). However, severe eosinophilic asthma may be resistant to both inhaled and systemic 
corticosteroids, also because of an excessive bronchial amount of IL-5, which can thereby overcome the pro-apoptotic effects of these drugs on eosinophils (Dunican and Fahy, 2017). Hence, patients with severe T2-high eosinophilic asthma, refractory to corticosteroids, may experience an inadequate control of respiratory symptoms and frequent disease exacerbations, thus being characterized by relevant unmet needs. Moreover, in these subjects, IL-5-dependent eosinophilia can also contribute to the development of clinically significant comorbidities such as chronic rhinosinusitis with nasal polyps. Indeed, these upper airway disorders originate from cellular and molecular mechanisms, which appear to be very similar to those underlying type 2 inflammation in asthma (Heffler et al., 2018, 2019; Ahern and Cervin, 2019).

For all such reasons, in severe T2-high asthma, IL-5 represents a pivotal pathogenic factor and a highly valuable target for add-on biological therapies of corticosteroid-resistant, difficult-to-treat eosinophilic phenotypes (Varricchi and Canonica, 2016; Brussino et al., 2018). In particular, several monoclonal antibodies have been developed against either IL-5 (mepolizumab, reslizumab) or its receptor (benralizumab), thereby making it possible to break down the main pathobiological pathway implicated in eosinophilic asthma (Egan et al., 1999; Gnanakumaran and Babu, 2003; Kolbeck et al., 2010; Pelaia et al., 2016; Bagnasco et al., 2017; Pelaia et al., 2017; Varricchi et al., 2017a,b; Bagnasco et al., 2018a,b; Pelaia et al., 2018a,b,c, 2019).

Taking together the above considerations, it is very clear that IL-5 plays a central role as the most important pathogenic mediator responsible for eosinophilic asthma, as well as a crucial therapeutic target for anti-asthma biological treatments. Therefore, the aim of the present review article is to discuss the pathobiological interactions between IL-5 and T2-high eosinophilic asthma, the mechanism of action of IL-5, and the relevance of both this cytokine and its receptor as targets of selective anti-eosinophil monoclonal antibodies.

\section{IL-5 AND EOSINOPHILIC ASTHMA}

The main cellular sources of IL-5 include T helper-2 (Th2) lymphocytes and group 2 innate lymphoid cells (ILC2) (Figure 1; Woodruff et al., 2009; Brusselle et al., 2013; Walker et al., 2013; Smith et al., 2016; Yanagibashi et al., 2017). Th2 cells produce and secrete IL-5 upon a complex activation process triggered by inhaled allergens and driven by dendritic cells (Lambrecht et al., 2019). In this regard, the presence of interleukin-4 (IL-4) is essential, because of its requirement for Th2 cell commitment and activation via stimulation of key transcription factors such as STAT6 and GATA3 (Lambrecht and Hammad, 2015). IL-5 release from ILC2 is dependent on GATA3 activation induced by epithelial innate cytokines including IL-25, IL-33, and especially thymic stromal lymphopoietin (TSLP) (Figure 1; Lambrecht and Hammad, 2015). In addition to ILC2 and Th2 cells, other cellular sources of IL-5 include invariant natural killer (NK) T cells, mast cells, and eosinophils themselves (Figure 1; Shakoory et al., 2004; Sakuishi et al., 2007; Hogan et al., 2008). In particular, by releasing IL-5 activated mast cells implement a bidirectional cross-talk with eosinophils (Galdiero et al., 2017). Such functional interactions between mast cells and eosinophils, also supported by physical contacts involving these two cell types, harbor the so-called "allergic effector unit" (Minai-Fleminger et al., 2010; Galdiero et al., 2017).

IL-5 is a powerful pro-inflammatory cytokine that is responsible for maturation, proliferation, activation, and migration of eosinophils (Figure 1). The close pathogenic link between IL-5 and eosinophilic inflammation has been clearly demonstrated using both animal and human experimental models of asthma (Greenfeder et al., 2001). In particular, IL-5 is responsible for airway eosinophilia and bronchial hyperresponsiveness induced by allergen challenge in sensitized guinea pigs (Mauser et al., 1993). Moreover, in the lungs of these animals, an eosinophilic inflammatory response can be experimentally evoked by recombinant human IL-5 (Lilly et al., 1996). Similar to guinea pigs, upon allergen challenge, an IL-5-dependent influx of eosinophils was also detected in bronchoalveolar lavage fluid (BALF) and lung tissue of sensitized mice (Kung et al., 1994, 1995). Such results have been further corroborated by demonstrating that bronchial eosinophilia and airway hyperresponsiveness, induced by multiple allergen challenges, were abrogated in sensitized IL-5-deficient mice (Foster et al., 1996; Kopf et al., 1996). In experimental monkey models of asthma, IL-5 was capable of inducing bronchial eosinophilia and the consequent airway hyperresponsiveness (Mauser et al., 1995). Furthermore, it has been shown in both rabbits and humans that delivery of recombinant IL-5 to airway smooth muscle enhanced the contractile response to acetylcholine (Hakonarson et al., 1999), and this effect was probably mediated by the release of eosinophil granule proteins (Elbon et al., 1995). In atopic patients experiencing both early and late asthmatic reactions, the bone marrow responds to antigen challenge by enhancing the production of eosinophils, which resulted in being associated with an increase in IL-5 mRNA levels (Wood et al., 2002). In addition, IL-5 prolonged eosinophil survival in allergen-challenged atopic asthmatics (Ohnishi et al., 1993).

In allergic asthmatic subjects, the eosinophilopoietic actions of IL-5 take place in both bone marrow and bronchial mucosa ("in situ eosinophilopoiesis"), where this cytokine promotes eosinophil differentiation and maturation from CD34+ hematopoietic progenitor cells (Wood et al., 2002; Dorman et al., 2004; Bhalla et al., 2018). In fact, elevated IL-5 levels and high cell counts of eosinophil progenitors and mature eosinophils can be found in induced sputum from patients with allergic asthma (Dorman et al., 2004). Furthermore, in comparison to both healthy controls and subjects with mild asthma, higher serum IL-5 concentrations were detected in patients with severe disease (Greenfeder et al., 2001). IL-5 synergizes with eotaxins, thus contributing to recruit eosinophils to asthmatic airways (Fulkerson and Rothenberg, 2013). Indeed, high levels of IL-5 and eotaxins were found in induced sputum from patients experiencing acute asthma exacerbations (Park et al., 2003). A synergic action is also exerted by IL-5 in conjunction with IL-18 (Kandikattu et al., 2019). In particular, concomitant increases of serum levels of IL-5 and IL-18 were found in patients with asthma, and the concentrations of these 


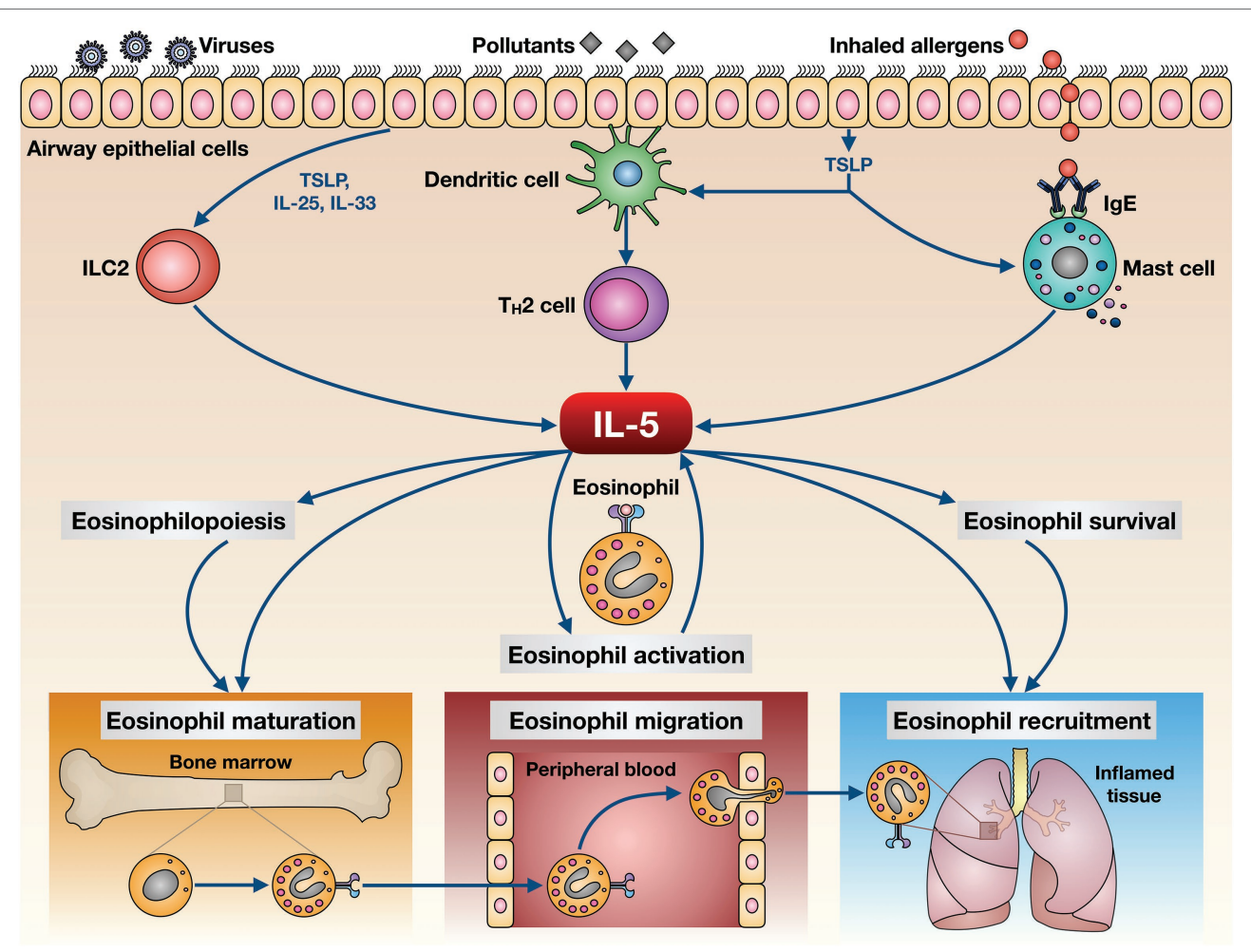

FIGURE 1 | Biological actions exerted by IL-5 on eosinophils. IL-5 is produced by several cellular elements, including Th2 lymphocytes, group 2 innate lymphoid cells (ILC2), mast cells, and eosinophils. These cells release IL-5 upon activation triggered by multiple environmental stimuli such as inhaled allergens, respiratory viruses, and airborne pollutants. IL-5 exerts pleiotropic effects on eosinophils, thereby promoting their maturation, activation, survival, migration from bloodstream, and recruitment to airways.

two cytokines correlated with disease exacerbations (Kandikattu et al., 2019). IL-5 and IL-18 strongly cooperate to induce eosinophil development and functional activation. IL-5 also inhibits eosinophil apoptosis, and sputum IL-5 levels were reported to be negatively correlated with apoptotic eosinophils in subjects with either asthma exacerbations or stable disease (Xu et al., 2007; Ilmarinen et al., 2014). Moreover, in T2-high asthma IL-5 induces eosinophil adhesion to and migration in the extracellular matrix by favoring the interaction of eosinophils with periostin, a matricellular protein whose enhanced expression is associated with eosinophil trafficking toward bronchi (Johansson, 2017). IL-5 is also involved in the pathobiology of late-onset, non-allergic eosinophilic asthma (Brusselle et al., 2013). In this case, ILC2 and not Th2 lymphocytes are mainly responsible for IL-5 production (Walker et al., 2013). Differently from blood and airway pro-inflammatory eosinophils, the lung resident subsets of homeostatic anti-inflammatory and antiallergic eosinophils seem to be partially independent from IL-5, at least in mice (Marichal et al., 2017).

With regard to the pathobiology of asthma, in addition to promoting the development and amplification of eosinophilic inflammation, IL-5 is also implicated in the induction of airway remodeling (Kay et al., 2004). Indeed, in murine models of asthma, it has been shown that IL-5 gene deletion was associated with a parallel suppression of both lung eosinophilia and bronchial remodeling (Cho et al., 2004). On the other hand, IL-5 transgenic mice were reported to be characterized by an enhanced airway fibrotic response to repeated allergen challenges (Tanaka et al., 2004). The results of these animal studies have been further corroborated by examining the bronchial biopsies taken from asthmatic patients treated with an anti-IL-5 monoclonal antibody (Flood-Page et al., 2003). In particular, it was demonstrated through confocal microscopy that anti-IL-5 treatment decreased the thickness of reticular basement membrane by reducing the deposition of extracellular matrix proteins such as procollagen III, tenascin, and lumican (Flood-Page et al., 2003).

\section{IL-5: MECHANISM OF ACTION}

The biological effects of IL- 5 are mediated by its selective interaction with the IL-5 receptor (IL-5R), consisting of a specific $\alpha$ subunit (IL-5R $\alpha$ ) and a non-specific $\beta c$ heterodimer, which can be recognized also by interleukin-3 (IL-3) and granulocytemacrophage colony stimulating factor (GM-CSF) (Figure 2; Rossjohn et al., 2000; Murphy and Young, 2006). IL-5 binds as a homodimeric protein to IL-5R $\alpha$, which is highly expressed on eosinophil surface (Varricchi et al., 2016), thus recruiting the $\beta c$ dimer and inducing the assembly of the IL-5/IL-5R $\alpha / \beta c$ ternary complex (Broughton et al., 2012). When IL-5 is absent, IL-5R $\alpha$ is complexed with the intracellular tyrosine kinase Janus kinase 


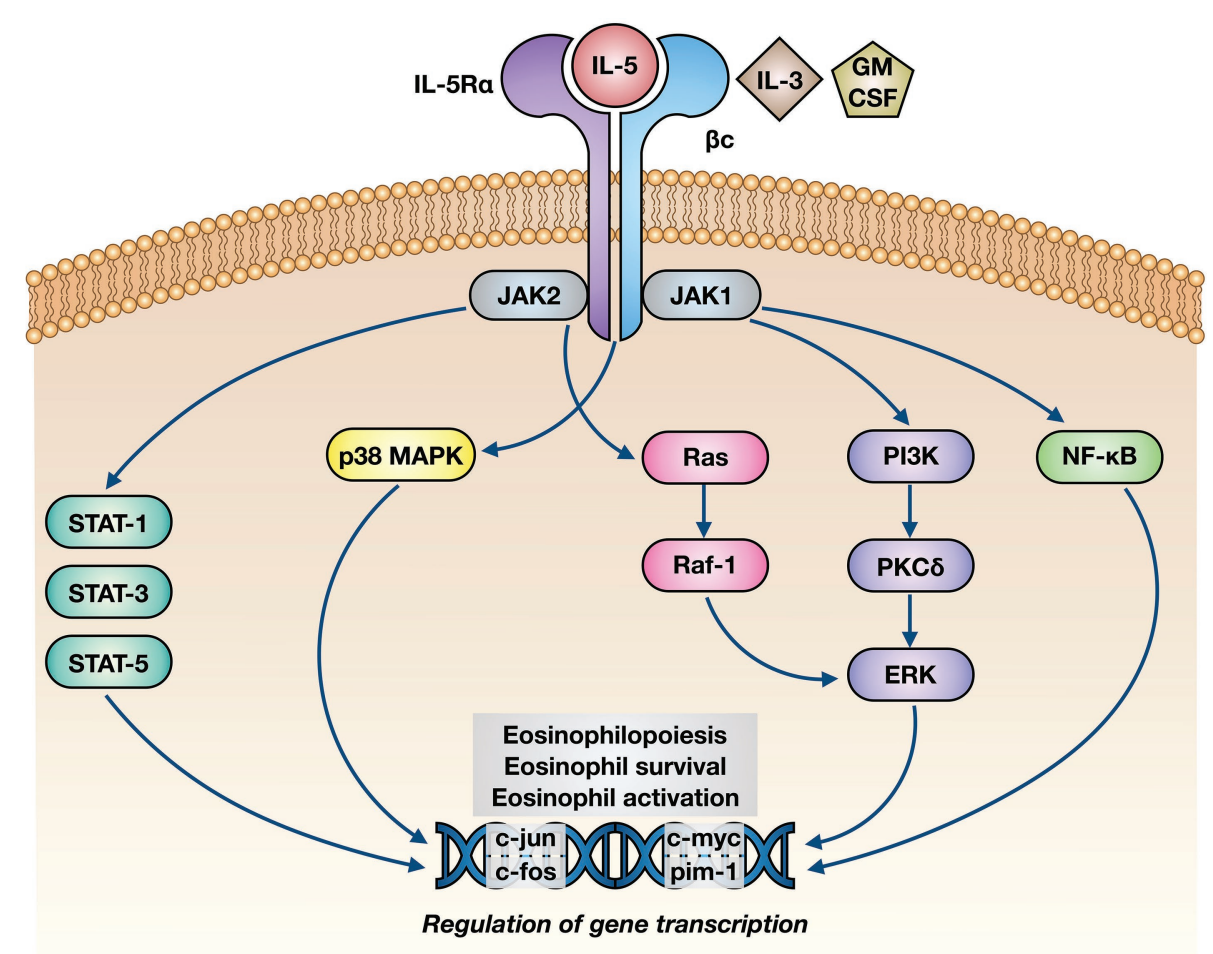

FIGURE 2 | Molecular mechanisms of action underlying the effects of IL-5 on eosinophils. IL-5 binds to the $\alpha$ subunit of IL-5 receptor (IL-5R $\alpha$ ), thereby inducing its interaction with $\beta \mathrm{c}$ subunits and the following activation of a complex intracellular signaling network, consisting of JAK1/2-STAT1/3/5 modules, p38 and ERK MAP kinases, and NF-кB transcription factor. The consequent stimulation of specific target genes leads to eosinophil maturation, survival, and activation.

(JAK)2, whereas the $\beta c$ subunit is associated with JAK1 (Kouro and Takatsu, 2009). When IL-5 is present, it binds to IL-5R $\alpha$ and drives the constitution of a functional IL-5R $\alpha / \beta c$ receptor complex, which is responsible for the activation of an intricate network of signaling pathways (Figure 2; Johanson et al., 1995; Ishino et al., 2008; Molfino et al., 2012). In particular, binding of IL- 5 to IL- 5 R $\alpha$ sequentially activates JAK2 and signal transducers and activators of transcription (STAT) 1, 3, and 5, which in turn stimulate the transcriptional functions of many genes involved in eosinophil proliferation, including pim-1 and cyclin D3 (Pazdrak et al., 1995; Stout et al., 2004). Moreover, JAK2 is engaged in active cooperation with Lyn and Raf-1 kinases, and such functional interactions lead to inhibition of eosinophil apoptosis (Pazdrak et al., 1998); the inhibitory effect of IL-5 on eosinophil apoptosis is also mediated by NF- $\mathrm{KB}$-dependent induction of the antiapoptotic protein Bcl-xL (Schwartz et al., 2015; Amruta and Kandikattu, 2018). Raf-1 also stimulates eosinophil degranulation (Pazdrak et al., 1998).

Other signal transduction modules activated by IL-5 include further intracellular kinases such as phosphoinositide 3-kinase (PI3K) and mitogen-activated protein kinases (MAPK) (Figure 2). In particular, via activation of extracellular signalregulated kinases (ERK) $1 / 2$ and protein kinase C (PKC), PI3K mediates IL-5-induced interaction of eosinophils with intercellular adhesion molecule-1 (ICAM-1) (Sano et al., 2005). Ras-Raf1-mediated activation of the ERK subfamily of MAPK drives c-fos gene transcription, which is involved in several eosinophil functions including cell maturation, survival, and proliferation, as well as stimulation of the production of the powerful eosinophil chemoattractant leukotriene C4 (Adachi and Alam, 1998; Bates et al., 2000; Pelaia et al., 2005; Takatsu and Nakajima, 2008; Thompson-Souza et al., 2017). Furthermore, through a NF-кB-dependent mechanism, p38 MAPK up-regulates eosinophil biosynthesis of pro-inflammatory cytokines, and also stimulates eosinophil recruitment within the context of allergic inflammatory responses (Adachi et al., 2000; Ip et al., 2005; Pelaia et al., 2005).

Therefore, because of the pivotal role played by IL-5 in the pathophysiology of T2-high asthma, this cytokine and its receptor represent key molecular targets for current biological therapies aimed to improve the control of severe and difficult-to-treat eosinophilic disease (Varricchi et al., 2016; Bagnasco et al., 2018a,b; McGregor et al., 2019; Siddiqui et al., 2019).

\section{IL-5 AND ITS RECEPTOR: MOLECULAR TARGETS FOR BIOLOGICAL THERAPIES OF SEVERE ASTHMA}

In clinical practice, three monoclonal antibodies, namely mepolizumab, reslizumab, and benralizumab, are currently available, which make it possible to effectively interfere with the pathogenic IL-5/IL-5R pro-eosinophilic axis. While mepolizumab 
and reslizumab are selective IL-5 inhibitors, benralizumab is an IL-5 receptor antagonist (Figure 3).

Mepolizumab (SB-240563) is a humanized IgG1/k monoclonal antibody that specifically binds with high affinity to IL-5, thereby impeding its linkage to IL-5R $\alpha$ (Figure 3; Gnanakumaran and Babu, 2003; Walsh, 2015; Fainardi et al., 2016; Varricchi et al., 2017a). In particular, mepolizumab was developed by incorporating specific murine antibody fragments targeting human IL-5 into a human IgG1 heavy chain (Hart et al., 2001). The relevant benefits induced by mepolizumab in patients with severe refractory eosinophilic asthma have been clearly documented by many randomized controlled trials (RCT) (Pelaia et al., 2017; Varricchi et al., 2017a). Initially, the efficacy of mepolizumab was demonstrated by Nair et al. and Haldar et al. in a few patients with severe eosinophilic asthma experiencing frequent disease exacerbations (Haldar et al., 2009; Nair et al., 2009), These two seminal studies were the first ones to show that mepolizumab was able to significantly decrease asthma exacerbations, and this effect was concomitant with a sharp reduction of both sputum and blood eosinophils (Haldar et al., 2009; Nair et al., 2009). In addition to such results, using chest CT (computed tomography) scan, Haldar et al. also documented that mepolizumab decreased both thickness and total area of bronchial walls (Haldar et al., 2009). These observations corroborated previous findings published by FloodPage et al., who reported that mepolizumab was capable of reducing the amount of extracellular matrix proteins deposited within the sub-epithelial reticular basement membrane of airway mucosa; this effect was associated with decreased BALF concentrations of transforming growth factor- $\beta 1$ (TGF- $\beta 1$ ) (Flood-Page et al., 2003). Therefore, it can be inferred that the potential anti-remodeling effect of mepolizumab was probably a consequence of the depleting action exerted on eosinophils, which are important cellular sources of TGF- $\beta 1$, a prominent growth factor involved in the pathobiology of the airway structural changes occurring in asthma (Makinde et al., 2007).

Later, Pavord et al. performed the phase 2b/3 DREAM (Dose Ranging Efficacy And safety with Mepolizumab in severe asthma) trial, thus confirming, in a much larger study population, that mepolizumab lowered sputum and blood eosinophil levels, and also significantly decreased the asthma exacerbation rate (Pavord et al., 2012). Subsequently, two further studies named MENSA (MEpolizumab as adjunctive therapy iN patients with Severe Asthma) and SIRIUS (SteroId ReductIon with mepolizUmab Study) were conducted by Ortega et al. and Bel et al., respectively. Both trials demonstrated that, in patients with severe eosinophilic asthma, mepolizumab decreased the number of asthma exacerbations, improved symptom control and quality of life, and also induced a slight $\mathrm{FEV}_{1}$ (forced expiratory volume in $1 \mathrm{~s}$ ) increase (Bel et al., 2014; Ortega et al., 2014), Moreover, the SIRIUS trial provided convincing evidence about the oral corticosteroid-sparing action of mepolizumab, consisting of a 50\% decrease in prednisone intake (Bel et al., 2014). More recently, the phase IIIb MUSCA study, performed by Chupp et al., confirmed the ability of mepolizumab to improve health-related quality of life (Chupp et al., 2017). All these studies also showed that mepolizumab is characterized by a very good safety and tolerability profile. The main RCT referring to mepolizumab have been summarized in Table 1. In addition to RCT, mepolizumab is also undergoing evaluation within the context of real-life studies carried out in daily clinical practice. In this regard, preliminary data suggest that in a real-world setting mepolizumab can result in being even more effective than in RCT, and such findings might

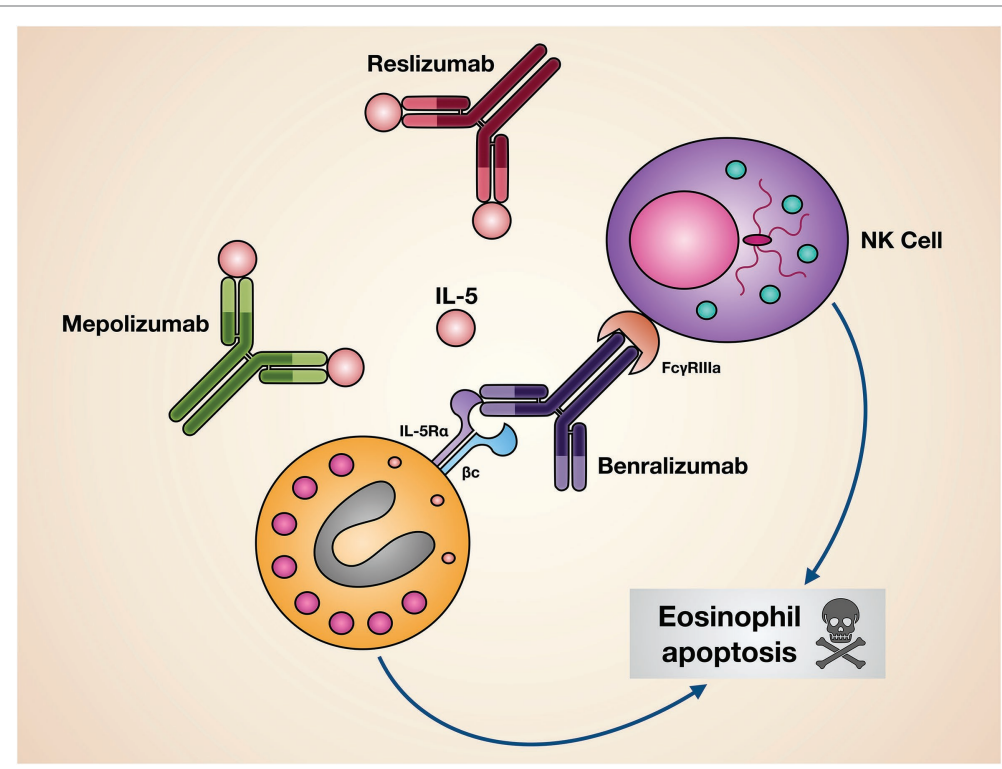

FIGURE 3 | Mechanisms of action of biological drugs targeting IL-5 or its receptor. Mepolizumab and reslizumab interact with IL-5, thus inhibiting its biological effects on eosinophils. Benralizumab blocks via its Fab fragments IL-5R $\alpha$, thereby neutralizing IL-5 bioactivity. Moreover, through its Fc constant region benralizumab binds to the Fc $\gamma$ IIIRa receptor expressed by natural killer cells, enabling them to induce eosinophil apoptosis. 
TABLE 1 | Mepolizumab: main randomized clinical trials.

\begin{tabular}{|c|c|c|c|}
\hline Authors & Inclusion criteria & $N$ & Main results \\
\hline Flood-Page et al. (2003) & Mild atopic asthmatics & 11 & $\downarrow$ Blood and BALF eosinophils \\
\hline \multirow[t]{3}{*}{ Haldar et al. (2009) } & Eosinophilic asthma & 61 & $\begin{array}{l}=\mathrm{FEV}_{1},=\mathrm{PEF},=\text { airway hyperresponsiveness } \\
\downarrow \text { Blood and sputum eosinophils }\end{array}$ \\
\hline & & & $=\mathrm{FEV}_{1},=\mathrm{FeNO},=$ airway hyperresponsiveness \\
\hline & & & $\downarrow$ Exacerbations \\
\hline & asthma & & $\downarrow$ Exacerbations \\
\hline \multirow[t]{3}{*}{ Pavord et al. (2012) } & Severe eosinophilic asthma & 462 & $\downarrow$ Blood and sputum eosinophils \\
\hline & & & $=\mathrm{FEV}_{1},=\mathrm{FeNO},=\mathrm{AQLQ},=\mathrm{ACQ}$ \\
\hline & & & $\downarrow$ Exacerbations \\
\hline Ortega et al. (2014) & Severe eosinophilic asthma & 385 & $\uparrow \mathrm{FEV}_{1}$ \\
\hline Bel et al. (2014) & & & ACQ-5 improvement \\
\hline \multirow[t]{2}{*}{ Chupp et al. (2017) } & Severe eosinophilic asthma & 274 & $\uparrow \mathrm{FEV}_{1}, \uparrow \mathrm{FEF}_{25-75}$ \\
\hline & & & ACQ-5 and SGRQ improvement \\
\hline
\end{tabular}

BALF, Bronchoalveolar lavage fluid; FEV, Forced expiratory volume in 1 s; PEF, Peak expiratory flow; FeNO, Exhaled fraction of nitric oxide; QoL, Health-related quality of life; AQLQ, Asthma quality of life questionnaire; ACQ, Asthma control questionnaire; SGRQ, St. George's Respiratory Questionnaire; OCS, Oral corticosteroids; FEF $25-75$, Forced expiratory flow at $25-75 \%$ of forced vital capacity.

depend on the higher blood eosinophil counts characterizing real-life patients when compared to asthmatics enrolled in RCT (Pelaia et al., 2018a; Bagnasco et al., 2018b).

Reslizumab (SCH55700) is a humanized IgG4/ $/$ monoclonal antibody which includes in its structure the complementaritydetermining regions of the rat monoclonal IgG2a antibody JES1-39D10, that specifically interact with the epitope encompassing amino acids 89-92 of human IL-5, thereby preventing its binding to IL-5R $\alpha$ (Figure 3; Zhang et al., 1999). In regard to add-on biological therapy of severe eosinophilic asthma, the efficacy and safety of reslizumab have been evaluated in several RCT (Pelaia et al., 2016; Varricchi et al., 2017b). The first phase 2 study was performed by Kips et al., who showed that reslizumab lowered blood and sputum eosinophil counts, and also induced a transient $\mathrm{FEV}_{1}$ increase (Kips et al., 2003). A subsequent, larger phase 2 trial, carried out by Castro et al., demonstrated that reslizumab significantly increased $\mathrm{FEV}_{1}$, and also elicited a non-significant trend toward a better asthma control, especially in highly eosinophilic patients with concomitant nasal polyposis (Castro et al., 2011), Later, two phase 3 studies were conducted by Castro et al., who demonstrated the effectiveness of reslizumab in decreasing by $50-59 \%$ the annual rate of asthma exacerbations in severe asthmatics with blood eosinophil counts $>400$ cells $/ \mathrm{ml}$ (Castro et al., 2015); reslizumab also improved asthma symptom control and enhanced $\mathrm{FEV}_{1}$ (Castro et al., 2015). The beneficial effects of reslizumab on lung function were further confirmed by another phase 3 trial carried out by Bjermer et al., who reported that reslizumab not only increased $\mathrm{FEV}_{1}$, but also improved airflow limitation at level of peripheral airways, as shown by significant increases
TABLE 2 | Reslizumab: main randomized clinical trials.

\begin{tabular}{|c|c|c|c|}
\hline Authors & $\begin{array}{l}\text { Inclusion } \\
\text { criteria }\end{array}$ & $N$ & Main results \\
\hline Kips et al. (2003) & Severe asthmatics & 18 & $\downarrow$ Blood and sputum eosinophils \\
\hline \multirow{3}{*}{$\begin{array}{l}\text { Castro et al. } \\
\text { (2011) }\end{array}$} & \multirow{3}{*}{$\begin{array}{l}\text { Poorly controlled } \\
\text { eosinophilic } \\
\text { asthma }\end{array}$} & \multirow[t]{3}{*}{61} & $\begin{array}{l}\text { Transient } \mathrm{FEV}_{1} \text { increase } \\
\downarrow \text { Blood and sputum eosinophils }\end{array}$ \\
\hline & & & $\uparrow \mathrm{FEV}_{1}, \uparrow \mathrm{FVC}$ \\
\hline & & & ACQ-5 improvement \\
\hline \multirow{4}{*}{$\begin{array}{l}\text { Castro et al. } \\
(2015)\end{array}$} & \multirow{4}{*}{$\begin{array}{l}\text { Severe } \\
\text { eosinophilic } \\
\text { asthma }\end{array}$} & \multirow[t]{4}{*}{953} & $\downarrow$ Blood eosinophils \\
\hline & & & $\uparrow \mathrm{FEV}_{1}$ \\
\hline & & & $\downarrow$ Exacerbations \\
\hline & & & $\begin{array}{l}\text { AQLQ, ACQ-7, ASUI } \\
\text { improvement }\end{array}$ \\
\hline \multirow{3}{*}{$\begin{array}{l}\text { Bjermer et al. } \\
\text { (2016) }\end{array}$} & \multirow{3}{*}{$\begin{array}{l}\text { Severe } \\
\text { eosinophilic } \\
\text { asthma }\end{array}$} & \multirow[t]{3}{*}{315} & $\downarrow$ Blood eosinophils \\
\hline & & & $\uparrow \mathrm{FEV}_{1}, \uparrow \mathrm{FEF}_{25-75}$ \\
\hline & & & $\begin{array}{l}\text { ACQ-5, ACQ-6, AQLQ, ASUI } \\
\text { improvement }\end{array}$ \\
\hline \multirow{2}{*}{$\begin{array}{l}\text { Brusselle et al. } \\
\text { (2017) }\end{array}$} & \multirow{2}{*}{$\begin{array}{l}\text { Severe } \\
\text { eosinophilic } \\
\text { asthma }\end{array}$} & \multirow[t]{2}{*}{477} & $\downarrow$ Exacerbations \\
\hline & & & $\uparrow \mathrm{FEV}_{1}$ \\
\hline
\end{tabular}

$F E V_{1}$, Forced expiratory volume in $1 \mathrm{~s}$; FVC, forced vital capacity; PEF, Peak expiratory flow; $A C Q$, Asthma control questionnaire; AQLQ, Asthma quality of life questionnaire; ASUI, Asthma symptom utility index; $F E F_{25-75}$, forced expiratory flow at $25-75 \%$ of forced vital capacity.

in $\mathrm{FEF}_{25-75}$ (forced expiratory flow at $25-75 \%$ of forced vital capacity) (Bjermer et al., 2016). More recently, an additional phase 3 trial performed by Brusselle et al. highlighted that reslizumab was able to reduce asthma exacerbations and improve 
lung function, especially in patients with eosinophilic late-onset asthma (Brusselle et al., 2017). Taken together, the results of the above studies evidenced a good safety and tolerability profile of reslizumab. The main RCT referring to reslizumab have been summarized in Table 2 .

TABLE 3 | Benralizumab: main randomized clinical trials.

\begin{tabular}{|c|c|c|c|}
\hline Authors & Inclusion criteria & $N$ & Main results \\
\hline Bleecker et al. (2016) & Severe asthma & 797 & $\begin{array}{l}\uparrow \mathrm{FEV}_{1} \\
\downarrow \text { Exacerbations } \\
\text { ACQ-6 and AQLQ } \\
\text { improvement }\end{array}$ \\
\hline $\begin{array}{l}\text { FitzGerald et al. } \\
\text { (2016) }\end{array}$ & $\begin{array}{l}\text { Severe eosinophilic } \\
\text { asthma }\end{array}$ & 866 & $\begin{array}{l}\uparrow \mathrm{FEV}_{1} \\
\downarrow \text { Exacerbations } \\
\text { ACQ-6 and AQLQ } \\
\text { improvement }\end{array}$ \\
\hline $\begin{array}{l}\text { Ferguson et al. } \\
(2017)\end{array}$ & $\begin{array}{l}\text { Severe eosinophilic } \\
\text { asthma }\end{array}$ & 106 & $\begin{array}{l}\downarrow \text { Blood eosinophils } \\
\uparrow \text { FEV }_{1} \\
=\text { ACQ- } 6,=\text { AQLQ }\end{array}$ \\
\hline Nair et al. (2017) & $\begin{array}{l}\text { Severe eosinophilic } \\
\text { asthma }\end{array}$ & 145 & $\begin{array}{l}\downarrow \text { Exacerbations } \\
\downarrow \text { OCS intake }\end{array}$ \\
\hline Busse et al. (2019) & $\begin{array}{l}\text { Severe eosinophilic } \\
\text { asthma }\end{array}$ & 1,576 & $\begin{array}{l}\text { Long-term safety and } \\
\text { tolerability }\end{array}$ \\
\hline
\end{tabular}

$F E V_{1}$, Forced expiratory volume in $1 \mathrm{~s}$; $A C Q$, Asthma control questionnaire; $A Q L Q$, Asthma quality of life questionnaire; OCS, Oral corticosteroids.
Benralizumab (MEDI-563) is a humanized afucosylated IgG1/א monoclonal antibody, developed via hybridoma technology, whose Fab fragments contain murine amino acid sequences which selectively recognize the isoleucine-61 residue of the domain 1 of human IL-5R $\alpha$, located near IL-5 binding site (Ishino et al., 2004; Koike et al., 2009; Kolbeck et al., 2010). As a consequence, the interaction of benralizumab with its recognition site on IL-5R $\alpha$ impedes IL-5 binding to target cells (Figure 3), thus preventing hetero-dimerization of IL-5R $\alpha$ and $\beta c$ subunits, as well as the subsequent activation of IL-5-dependent signaling pathways. Furthermore, through the constant $F c$ region benralizumab binds to the Fc $\gamma$ RIIIa membrane receptor expressed by natural killer cells (Figure 3), which upon FcyRIIIa activation release the pro-apoptotic proteins granzyme B and perforin, responsible for eosinophil apoptosis implemented via antibodydependent cell-mediated cytotoxicity (ADCC), a mechanism which is markedly amplified by afucosylation (Shields et al., 2002; Ghazi et al., 2012).

Several phase 3 RCT have recently shown that, as add-on treatment of severe eosinophilic asthma, benralizumab is characterized by an excellent pattern of efficacy, safety, and tolerability (Pelaia et al., 2018b,c; Gonzalez et al., 2019). In particular, CALIMA and SIROCCO trials showed that benralizumab significantly decreased the annual rate of severe eosinophilic exacerbations of asthma, and also improved asthma symptom control and enhanced $\mathrm{FEV}_{1}$ (Bleecker et al., 2016; FitzGerald et al., 2016). Benralizumab-induced improvement in

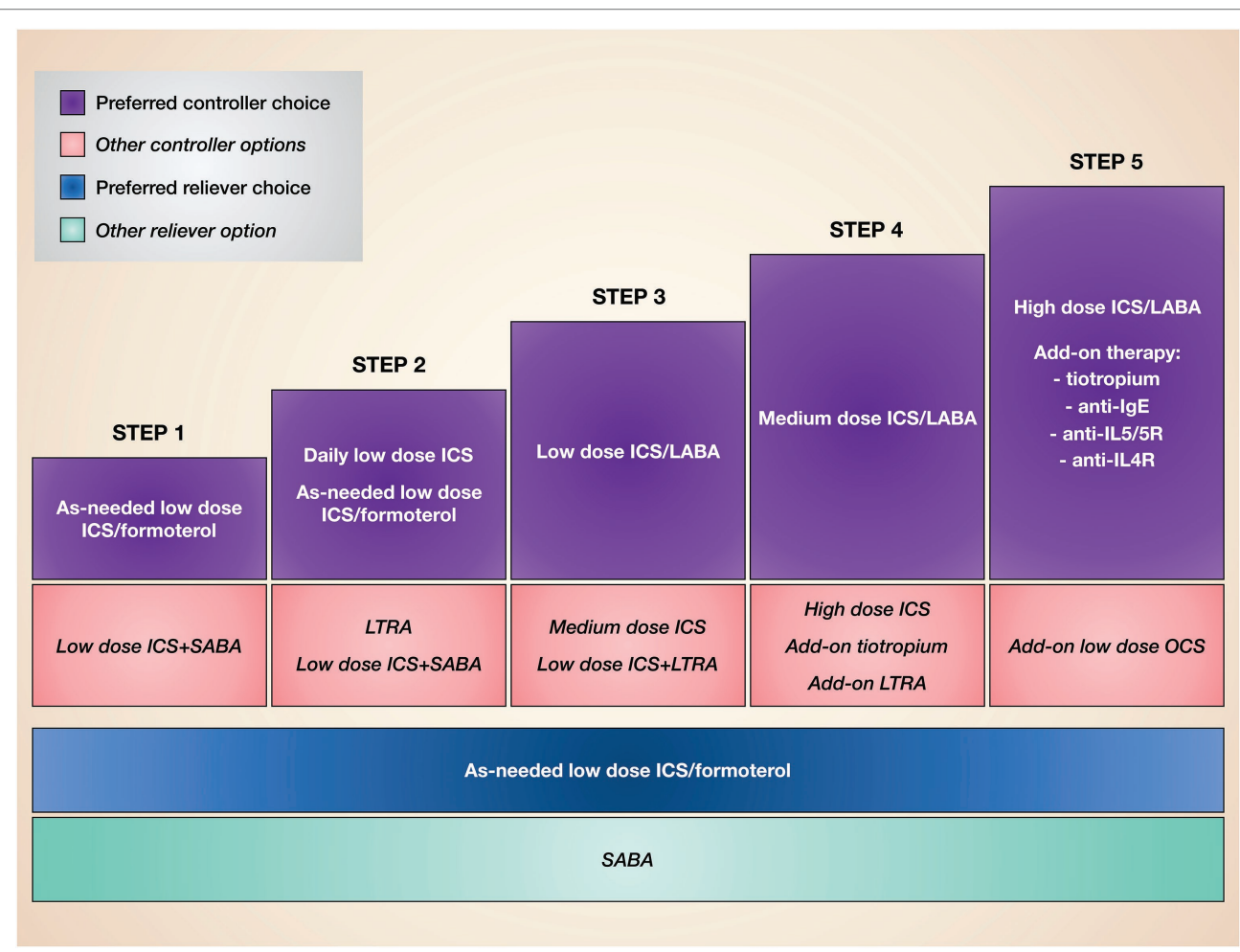

FIGURE 4 | Stepwise therapy of asthma. Current asthma treatment is based on a stepwise approach, consisting of progressive therapeutic increases until disease control is achieved. 
lung function was also confirmed by BISE study (Ferguson et al., 2017). In addition, the ZONDA study demonstrated that benralizumab was able to significantly lower the daily intake of oral corticosteroids (Nair et al., 2017). Moreover, the BORA trial showed that a long-term use of benralizumab was associated with a very good safety and tolerability profile (Busse et al., 2019). Furthermore, it is noteworthy that benralizumab appears to be very effective in both allergic and non-allergic severe asthma (Chipps et al., 2018). The main RCT referring to benralizumab have been summarized in Table 3. The latter findings have also been recently confirmed by preliminary real-life observations, which suggest that in daily clinical practice the therapeutic actions of benralizumab may result in being even more rapid and effective with respect to RCT (Pelaia et al., 2019).

In regard to IL-5 receptor blockade finalized to the treatment of eosinophilic asthma, a potential alternative approach to the use of monoclonal antibodies can be represented by the development of small molecule antagonists (Uings and McKinnon, 2002). Within such a context, an isothiazolone compound was identified, which appeared to be able to selectively interfere with IL-5/IL-5R interaction (Devos et al., 1994; Uings and McKinnon, 2002). However, to our knowledge this small molecule IL-5R antagonist has not yet reached the stage of clinical investigation.

\section{CONCLUDING REMARKS}

Our very strong awareness of the pivotal pathobiological role played by IL-5 in T2-high eosinophilic asthma makes it critical to carefully characterize asthmatic patients on the basis of their inflammatory substrate, as well as in consideration of

\section{REFERENCES}

Adachi, T., and Alam, R. (1998). The mechanism of IL-5 signal transduction. Am. J. Phys. 275, C623-C633. doi: 10.1152/ajpcell.1998.275.3.C623

Adachi, T., Choudhuri, B. K., Stafford, S., Sur, S., and Alam, R. (2000). The differential role of extracellular signal-regulated kinases and p38 mitogenactivated protein kinase in eosinophil functions. J. Immunol. 165, 2198-2204. doi: 10.4049/jimmunol.165.4.2198

Ahern, S., and Cervin, A. (2019). Inflammation and endotyping in chronic rhinosinusitis—a paradigm shift. Medicina 55:E95. doi: 10.3390/medicina55040095 Amruta, N., and Kandikattu, H. K. (2018). Apoptosis of inflammatory cells in asthma. Int. J. Cell Biol. Physiol. 1, 1-6. doi: 10.5281/zenodo.2530304

Anderson, W. C. III., and Szefler, S. J. (2019). Cost-effectiveness and comparative effectiveness of biologic therapy for asthma. Ann. Allergy Asthma Immunol. 122, 367-372. doi: 10.1016/j.anai.2019.01.018

Bagnasco, D., Caminati, M., Ferrando, M., Aloè, T., Testino, E., Canonica, G. W., et al. (2018a). Anti-IL-5 and IL-5R $\alpha$ : efficacy and safety of new therapeutic strategies in severe uncontrolled asthma. Biomed. Res. Int. 2018:5698212. doi: 10.1155/2018/5698212

Bagnasco, D., Ferrando, M., Varricchi, G., Puggioni, F., Passalacqua, G., Canonica, G. W., et al. (2017). Anti-interleukin 5 (IL-5) and IL-5R $\alpha$ biological drugs: efficacy, safety, and future perspectives in severe eosinophilic asthma. Front. Med. 4:135. doi: 10.3389/fmed.2017.00135

Bagnasco, D., Milanese, M., Rolla, G., Lombardi, C., Bucca, C., Heffler, E., et al. (2018b). The North-Western Italian experience with anti IL-5 therapy and comparison with regulatory trials. World Allergy Organ. J. 11:34. doi: 10.1186/s40413-018-0210-7

Bates, M. E., Green, V. L., and Bertics, P. J. (2000). ERK1 and ERK2 activation by chemotactic factors in human eosinophils is interleukin 5 -dependent and the clinical and functional responses to standard treatments. Indeed, the most relevant unmet needs are experienced by both allergic and non-allergic asthmatics who are not well controlled by corticosteroids, also because of the prominent pro-eosinophilic action of IL-5, which probably overwhelms the potential efficacy of conventional anti-inflammatory drugs. Therefore, under such circumstances, IL-5 and its receptor may represent valuable therapeutic targets. In this regard, several RCT and some preliminary real-life studies have clearly shown that mepolizumab, reslizumab, and benralizumab are safe and effective as add-on biological therapies for patients with difficultto-treat eosinophilic asthma. Indeed, such biologics are currently included within the step 5 of GINA (Global Initiative for Asthma) guidelines (Figure 4; Global Initiative for Asthma, 2019). Therefore, the only limitation of these monoclonal antibodies depends on their high cost (Anderson and Szefler, 2019). Although the use of anti-eosinophilic biological treatments for severe asthma can significantly decrease the intake of oral corticosteroids, the number of emergency visits and hospitalizations, as well as the loss of work- and school-days, and their cost-effectiveness should be improved by price reductions eventually provided by manufacturers (Anderson and Szefler, 2019). Hopefully, lower costs of mepolizumab, reslizumab, and benralizumab could make these drugs more affordable by health care systems of economically weak countries.

\section{AUTHOR CONTRIBUTIONS}

All authors listed have made a substantial, direct and intellectual contribution to the work, and approved it for publication. contributes to leukotriene C4 biosynthesis. J. Biol. Chem. 275, 10968-10975. doi: $10.1074 /$ jbc.275.15.10968

Bel, E. H., Wenzel, S. E., Thompson, P. J., Prazma, C. M., Keene, O. N., Yancey, S. W., et al. (2014). Oral glucocorticoid-sparing effect of mepolizumab in eosinophilic asthma. N. Engl. J. Med. 371, 1189-1197. doi: 10.1056/NEJMoa1403291

Bhalla, A., Mukherjee, M., and Nair, P. (2018). Airway eosinophilopoietic and autoimmune mechanisms of eosinophilia in severe asthma. Immunol. Allergy Clin. N. Am. 38, 639-654. doi: 10.1016/j.iac.2018.06.003

Bjermer, L., Lemiere, C., Maspero, J., Weiss, S., Zangrilli, J., and Germinaro, M. (2016). Reslizumab for inadequately controlled asthma with elevated blood eosinophil levels: a randomized phase 3 study. Chest 150, 789-798. doi: 10.1016/j.chest.2016.03.032

Bleecker, E. R., FitzGerald, J. M., Chanez, P., Papi, A., Weinstein, S. F., Barker, P., et al. (2016). Efficacy and safety of benralizumab for patients with severe asthma uncontrolled with high-dosage inhaled corticosteroids and long-acting $\beta 2$-agonists (SIROCCO): a randomized, multicentre, placebo-controlled phase 3 trial. Lancet 388, 2115-2127. doi: 10.1016/ S0140-6736(16)31324-1

Bochner, B. S., and Gleich, G. J. (2010). What targeting eosinophils has taught us about their role in diseases. J. Allergy Clin. Immunol. 126, 16-25. doi: 10.1016/j.jaci.2010.02.026

Bousquet, J., Chanez, P., Lacoste, J. Y., Barnèon, G., Ghavanian, N., Enander, I., et al. (1990). Eosinophilic inflammation in asthma. N. Engl. J. Med. 323, 1033-1039. doi: 10.1056/NEJM199010113231505

Broughton, S. E., Dhagat, U., Hercus, T. R., Nero, T. L., Grimbaldeston, M. A., Bonder, C. S., et al. (2012). The GM-CSF/IL-3/IL-5 cytokine receptor family: from ligand recognition to initiation of signaling. Immunol. Rev. 250, 277-302. doi: 10.1111/j.1600-065X.2012.01164.X 
Brusselle, G., Germinaro, M., Weiss, S., and Zangrilli, J. (2017). Reslizumab in patients with inadequately controlled late-onset asthma and elevated blood eosinophils. Pulm. Pharmacol. Ther. 43, 39-45. doi: 10.1016/j.pupt.2017.01.011

Brusselle, G. G., Maes, T., and Bracke, K. R. (2013). Eosinophils in the spotlight: Eosinophilic airway inflammation in non allergic asthma. Nat. Med. 19, 977-979. doi: 10.1038/nm.3300

Brussino, L., Heffler, E., Bucca, C., Nicola, S., and Rolla, G. (2018). Eosinophils target therapy for severe asthma: critical points. Biomed. Res. Int. 2018:7582057. doi: $10.1155 / 2018 / 7582057$

Busse, E., Bleecker, R., FitzGerald, J. M., Ferguson, G. T., Barker, P., Sproule, S., et al. (2019). Long-term safety and efficacy of benralizumab in patients with severe, uncontrolled asthma: 1-year results from the BORA phase 3 extension trial. Lancet Respir. Med. 7, 46-59. doi: 10.1016/S2213-2600(18)30406-5

Castro, M., Mathur, S., Hargreave, F., Boulet, L. P., Xie, F., Young, J., et al. (2011). Reslizumab for poorly controlled, eosinophilic asthma: a randomized, placebo-controlled study. Am. J. Respir. Crit. Care Med. 184, 1125-1132. doi: $10.1164 / \mathrm{rccm} .201103-0396 \mathrm{OC}$

Castro, M., Zangrilli, J., Wechsler, M. E., Bateman, E. D., Brusselle, G. G., Bardin, P., et al. (2015). Reslizumab for inadequately controlled asthma with elevated blood eosinophil counts: results from two multicentre, parallel, double-blind, randomised, placebo-controlled, phase 3 trials. Lancet Respir. Med. 3, 355-366. doi: 10.1016/S2213-2600(15)00042-9

Chipps, B. E., Newbold, P., Hirsch, I., Trudo, F., and Goldman, M. (2018). Benralizumab efficacy by atopy status and serum immunoglobulin E for patients with severe, uncontrolled asthma. Ann. Allergy Asthma Immunol. 120, 504-511. doi: 10.1016/j.anai.2018.01.030

Cho, J. Y., Miller, M., Baek, K. J., Han, J. W., Nayar, J., and Lee, S. Y. (2004). Inhibition of airway remodeling in IL-5-deficient mice. J. Clin. Invest. 113, 551-560. doi: 10.1172/JCI19133

Chupp, G. L., Bradford, E. S., Albers, F. C., Bratton, D. J., Wang-Jairaj, J., Nelsen, L. M., et al. (2017). Efficacy of mepolizumab add-on therapy on health-related quality of life and markers of asthma control in severe eosinophilic asthma (MUSCA): a randomized, double-blind, placebo-controlled, parallel-group, multicenter, phase 3b trial. Lancet Respir. Med. 5, 390-400. doi: 10.1016/S2213-2600(17)30125-X

Devos, R., Guisez, Y., Plaetinck, G., Cornelis, S., Tavernier, J., van der Heyden, J., et al. (1994). Covalent modification of the interleukin- 5 receptor by isothiazolones leads to inhibition of the binding of interleukin-5. Eur. J. Biochem. 225, 635-640. doi: 10.1111/j.1432-1033.1994.00635.x

Dorman, S. C., Efthimiadis, A., Babirad, I., Watson, R. M., Denburg, J. A., Hargreave, F. E., et al. (2004). Sputum CD34+ IL-5R $\alpha+$ cells increase after allergen: evidence for in situ eosinophilopoiesis. Am. J. Respir. Crit. Care Med. 169, 573-577. doi: 10.1164/rccm.200307-1004OC

Dunican, E. M., and Fahy, J. V. (2017). Asthma and corticosteroids: time for a more precise approach to treatment. Eur. Respir. J. 49:1701167. doi: 10.1183/13993003.01167-2017

Egan, R. W., Athwal, D., and Bodmer, M. W. (1999). Effect of Sch 55700, a humanized monoclonal antibody to human interleukin-5, on eosinophilic responses and bronchial hyperreactivity. Arzneimittelforschung 49, 779-790. doi: $10.1055 / \mathrm{s}-0031-1300502$

Elbon, C. L., Jacoby, D. B., and Fryer, A. D. (1995). Pretreatment with an antibody to interleukin 5 prevents loss of pulmonary M2 muscarinic function in antigen challenged Guinea pigs. Am. J. Respir. Cell Mol. Biol. 12, 320-328. doi: $10.1165 /$ ajrcmb.12.3.7873198

Fainardi, V., Pisi, G., and Chetta, A. (2016). Mepolizumab in the treatment of severe eosinophilic asthma. Immunotherapy 8, 27-34. doi: 10.2217/imt.15.102

Ferguson, G. T., FitzGerald, J. M., Bleecker, E. R., Laviolette, M., Bernstein, D., LaForce, C., et al. (2017). Benralizumab for patients with mild to moderate persistent asthma (BISE): a randomised, double-blind, placebo-controlled phase 3 trial. Lancet Respir. Med. 5, 568-576. doi: 10.1016/S2213-2600(17)30190-X

FitzGerald, J. M., Bleecker, E. R., Nair, P., Korn, S., Ohta, K., Lommatzsch, M., et al. (2016). Benralizumab, an anti-interleukin-5 receptor $\alpha$ monoclonal antibody, as add-on treatment for patients with severe, uncontrolled eosinophilic asthma (CALIMA): a randomised, double-blind, placebo-controlled phase 3 trial. Lancet 388, 2128-2141. doi: 10.1016/S0140-6736(16)31322-8

Flood-Page, P., Menzies-Gow, A., Phipps, S., Ying, S., Wangoo, A., Ludwig, M. S., et al. (2003). Anti-IL-5 treatment reduces deposition of ECM proteins in the bronchial subepithelial basement membrane of mild atopic asthmatics. J. Clin. Invest. 112, 1029-1036. doi: 10.1172/JCI17974
Foster, P. S., Hogan, S. P., Ramsay, A. J., Matthaei, K. I., and Young, I. G. (1996). Interleukin 5 deficiency abolishes eosinophilia, airway hyperreactivity, and lung damage in a mouse asthma model. J. Exp. Med. 183, 195-201. doi: $10.1084 /$ jem.183.1.195

Fulkerson, P. C., and Rothenberg, M. E. (2013). Targeting eosinophils in allergy, inflammation and beyond. Nat. Rev. Drug Discov. 12, 117-129. doi: 10.1038/ $\operatorname{nrd} 3838$

Galdiero, M. R., Varricchi, G., Seaf, M., Marone, G., Levi-Schaffer, F., and Marone, G. (2017). Bidirectional mast cell-eosinophil interactions in inflammatory disorders and cancer. Front. Med. 4:103. doi: 10.3389/ fmed.2017.00103

Ghazi, A., Trikha, A., and Calhoun, W. J. (2012). Benralizumab - a humanized $\mathrm{mAb}$ to IL-5R $\alpha$ with enhanced antibody-dependent cell-mediated cytotoxicity - a novel approach for the treatment of asthma. Expert. Opin. Biol. Ther. 12, 113-118. doi: 10.1517/14712598.2012.642359

Global Initiative for Asthma (2019). Update. Available at: www.ginasthma.org (Accessed October 1, 2019).

Gnanakumaran, G., and Babu, K. S. (2003). Technology evaluation: mepolizumab, GlaxoSmithKline. Curr. Opin. Mol. Ther. 5, 321-325

Gonzalez, D., Benitez, M., and Quirce, S. (2019). Benralizumab: a new approach for the treatment of severe eosinophilic asthma. J. Investig. Allergol. Clin. Immunol. 29, 84-93. doi: 10.18176/jiaci.0385

Greenfeder, S., Umland, S. P., Cuss, F. M., Chapman, R. W., and Egan, R. W. (2001). Th2 cytokines and asthma. The role of interleukin-5 in allergic eosinophilic disease. Respir. Res. 2, 71-79. doi: 10.1186/rr41

Hakonarson, H., Maskeri, N., Carter, C., Chuang, S., and Grunstein, M. M. (1999). Autocrine interaction between IL-5 and IL-1beta mediates altered responsiveness of atopic asthmatic sensitized airway smooth muscle. J. Clin. Invest. 104, 657-667. doi: 10.1172/JCI7137

Haldar, P. (2017). Patient profiles and clinical utility of mepolizumab in severe eosinophilic asthma. Biol. Ther. Dent. 11, 81-95. doi: 10.2147/BTT.S93954

Haldar, P., Brightling, C. E., Hargadon, B., Gupta, S., Monteiro, W., Sousa, A., et al. (2009). Mepolizumab and exacerbations of refractory eosinophilic asthma. N. Engl. J. Med. 360, 973-984. doi: 10.1056/NEJMoa0808991

Hart, T. K., Cook, R. M., Zia-Amirhosseini, P., Minthorm, E., Sellers, T. S., Maleeff, B. E., et al. (2001). Preclinical efficacy and safety of mepolizumab (SB-240563), a humanized monoclonal antibody to IL-5, in cynomolgus monkeys. J. Allergy Clin. Immunol. 108, 250-257. doi: 10.1067/mai.2001.116576

Heffler, E., Malvezzi, L., Boita, M., Brussino, L., De Virgilio, A., Ferrando, M., et al. (2018). Immunological mechanisms underlying chronic rhinosinusitis with nasal polyps. Expert. Rev. Clin. Immunol. 14, 731-737. doi: 10.1080/1744666X.2018.1512407

Heffler, E., Malvezzi, L., Pirola, F., Zieba, N., Paoletti, G., Mercante, G., et al. (2019). Treatable traits in chronic rhinosinusitis with nasal polyps. Curr. Opin. Allergy Clin. Immunol. 19, 373-378. doi: 10.1097/ ACI.0000000000000544

Hogan, S. P., Rosenberg, H. F., Moqbel, R., Phipps, S., Foster, P. S., Lacy, P., et al. (2008). Eosinophils: biological properties and role in health and disease. Clin. Exp. Allergy 38, 709-750. doi: 10.1111/j.1365-2222.2008.02958.x

Holgate, S. T., Wenzel, S., Postma, D. S., Weiss, S. T., Renz, H., and Sly, D. (2015). Asthma. Nat. Rev. Dis. Primers 1:15025. doi: 10.1038/nrdp.2015.25

Houston, J. C., De Navasquez, S., and Trounce, J. R. (1953). A clinical and pathological study of fatal cases of status asthmaticus. Thorax 8, 207-213. doi: $10.1136 /$ thx.8.3.207

Huber, K. L., and Koessler, K. (1922). The pathology of bronchial asthma. Arch. Intern. Med. 30, 689-760. doi: 10.1001/archinte.1922.00110120002001

Ilmarinen, P., Moilanen, E., and Kankaanranta, H. (2014). Regulation of spontaneous eosinophil apoptosis - a neglected area of importance. J. Cell Death 7, 1-9. doi: 10.4137/JCD.S13588

Ip, W. K., Wong, C. K., Wang, C. B., Tian, Y. P., and Lam, C. W. (2005). Interleukin-3, -5, and granulocyte macrophage colony-stimulating factor induce adhesion and chemotaxis of human eosinophils via p38 mitogenactivated protein kinase and nuclear factor kappaB. Immunopharmacol. Immunotoxicol. 27, 371-393. doi: 10.1080/08923970500240925

Ishino, T., Harrington, A. E., Gopi, H., and Chaiken, I. (2008). Structure-based rationale for interleukin 5 receptor antagonism. Curr. Pharm. Des. 14, 1231-1239. doi: 10.2174/138161208784246144

Ishino, T., Pasut, G., Scibek, J., and Chaiken, I. (2004). Kinetic interaction analysis of human interleukin 5 receptor $\alpha$ mutants reveals a unique binding 
topology and charge distribution for cytokine recognition. J. Biol. Chem. 279, 9547-9556. doi: 10.1074/jbc.M309327200

Johanson, K., Appelbaum, E., Doyle, M., Hensley, P., Zhao, B., Abdel-Meguid, S. S., et al. (1995). Binding interactions of human interleukin 5 with its receptor $\alpha$ subunit. Large scale production, structural, and functional studies of Drosophila-expressed recombinant proteins. J. Biol. Chem. 270, 9459-9471. doi: $10.1074 / j b c .270 .16 .9459$

Johansson, M. V. (2017). Eosinophil activation status in separate compartments and association with asthma. Front. Med. 4:75. doi: 10.3389/fmed.2017.00075

Kandikattu, H. K., Venkateshaiah, S. U., and Mishra, A. (2019). Synergy of interleukin (IL)-5 and IL-18 in eosinophil mediated pathogenesis of allergic diseases. Cytokine Growth Factor Rev. 47, 83-98. doi: 10.1016/j. cytogfr.2019.05.003

Kay, A. B., Phipps, S., and Robinson, D. S. (2004). A role for eosinophils in airway remodelling in asthma. Trends Immunol. 25, 477-482. doi: 10.1016/j. it.2004.07.006

Kips, J. C., O’Connor, B. J., Langley, S. J., Woodcock, A., Kerstjens, H. A., Postma, D. S., et al. (2003). Effects of SCH55700, a humanized anti-human interleukin-5 antibody, in severe persistent asthma: a pilot study. Am. J. Respir. Crit. Care Med. 167, 1655-1659. doi: 10.1164/rccm.200206-525OC

Koike, M., Nakamura, K., Furuya, A., Iida, A., Anazawa, H., Takatsu, K., et al. (2009). Establishment of humanized anti-interelukin-5 receptor $\alpha$ chain monoclonal antibodies having a potent neutralizing activity. Hum. Antibodies 18, 17-27. doi: 10.3233/HAB-2009-0198

Kolbeck, R., Kozhich, A., Koike, M., Peng, L., Andersson, C. K., Damschroder, M. M., et al. (2010). Medi-563, a humanized anti-IL-5 receptor $\alpha \mathrm{mAb}$ with enhanced antibody-dependent cell mediated cytotoxicity function. J. Allergy Clin. Immunol. 125, 1344-1353. doi: 10.1016/j.jaci.2010.04.004

Kopf, M., Brombacher, F., Hodgkin, P. D., Ramsay, A. J., Milbourne, E. A., Dai, W. J., et al. (1996). IL-5 deficient mice have a developmental defect in CD5+ B-1 cells and lack eosinophilia but have normal antibody and cytotoxic $\mathrm{T}$ cell responses. Immunity 4, 15-24. doi: 10.1016/S1074-7613(00)80294-0

Kouro, T., and Takatsu, K. (2009). IL-5- and eosinophil-mediated inflammation: from discovery to therapy. Int. Immunol. 21, 1303-1309. doi: 10.1093/intimm/ dxp102

Kung, T. T., Jones, H., Adams, G. K. III., Umland, S. P., Kreutner, W., Egan, R. W., et al. (1994). Characterization of a murine model of allergic pulmonary inflammation. Int. Arch. Allergy Immunol. 105, 83-90. doi: 10.1159/000236807

Kung, T. T., Stelts, D. M., Zurcher, J. A., Adams, G. K. III., Egan, R. W., Kreutner, W., et al. (1995). Involvement of IL-5 in a murine model of allergic pulmonary inflammation: prophylactic and therapeutic effect of an anti-IL-5 antibody. Am. J. Respir. Cell Mol. Biol. 13, 360-365. doi: 10.1165/ ajrcmb.13.3.7654390

Lambrecht, B. N., and Hammad, H. (2015). The immunology of asthma. Nat. Immunol. 16, 45-56. doi: 10.1038/ni.3049

Lambrecht, B. N., Hammad, H., and Fahy, J. V. (2019). The cytokines of asthma. Immunity 50, 975-991. doi: 10.1016/j.immuni.2019.03.018

Lilly, C. M., Chapman, R. W., Sehring, S. J., Mauser, P. J., Egan, R. W., and Drazen, J. M. (1996). Effects of interleukin 5-induced pulmonary eosinophilia on airway reactivity in the Guinea pig. Am. J. Phys. 270, L368-L375. doi: 10.1152/ajplung.1996.270.3.L368

Makinde, T., Murphy, R. F., and Agrawall, D. K. (2007). The regulatory role of TGF-beta in airway remodeling in asthma. Immunol. Cell Biol. 85, 348-356. doi: 10.1038/sj.icb.7100044

Marichal, T., Mesnil, C., and Bureau, F. (2017). Homeostatic eosinophils: characteristics and functions. Front. Med. 4:101. doi: 10.3389/fmed.2017.00101

Mauser, P. J., Pitman, A. M., Fernandez, X., Foran, S. K., Adams, G. K. III., Kreutner, W., et al. (1995). Effects of an antibody to interleukin-5 in a monkey model of asthma. Am. J. Respir. Crit. Care Med. 152, 467-472. doi: 10.1164/ajrccm.152.2.7633694

Mauser, P. J., Pitman, A., Witt, A., Fernandez, X., Zurcher, J., Kung, T., et al. (1993). Inhibitory effect of the TRFK-5 anti-IL-5 antibody in a Guinea pig model of asthma. Am. Rev. Respir. Dis. 148, 1623-1628. doi: 10.1164/ ajrccm/148.6_Pt_1.1623

McGregor, M. C., Krings, J. G., Nair, P., and Castro, M. (2019). Role of biologics in asthma. Am. J. Respir. Crit. Care Med. 199, 433-445. doi: 10.1164/ rccm.201810-1944CI

Minai-Fleminger, Y., Elishmereni, M., Vita, F., Soranzo, M. R., Mankuta, D., Zabucchi, G., et al. (2010). Ultrastructural evidence for human mast cell- eosinophil interactions in vitro. Cell Tissue Res. 341, 405-415. doi: 10.1007/ s00441-010-1010-8

Molfino, N. A., Gossage, D., Kolbeck, R., Parker, J. M., and Geba, G. P. (2012). Molecular and clinical rationale for therapeutic targeting of interleukin-5 and its receptor. Clin. Exp. Allergy 42, 712-737. doi: 10.1111/j.1365-2222.2011.03854.x

Murphy, J. M., and Young, I. G. (2006). IL-3, IL-5, and GM-CSF signaling crystal structure of the human beta-common receptor. Vitam. Horm. 74, 1-30. doi: 10.1016/S0083-6729(06)74001-8

Nair, P., Pizzichini, M. M., Kjarsgaard, M., Inman, M. D., Efthimiadis, A., Pizzichini, E., et al. (2009). Mepolizumab for prednisone-dependent asthma with sputum eosinophilia. N. Engl. J. Med. 360, 985-993. doi: 10.1056/ NEJMoa0805435

Nair, P., Wenzel, S., Rabe, K. F., Bourdin, A., Lugogo, N. L., Kuna, P., et al. (2017). Oral glucocorticoid-sparing effect of benralizumab in severe asthma. N. Engl. J. Med. 376, 2448-2458. doi: 10.1056/NEJMoa1703501

Ohnishi, T., Sur, S., Collins, D. S., Fish, J. E., Gleich, G. J., and Peters, S. P. (1993). Eosinophil survival activity identified as interleukin-5 is associated with eosinophil recruitment and degranulation and lung injury twenty-four hours after segmental antigen lung challenge. J. Allergy Clin. Immunol. 92, 607-615. doi: 10.1016/0091-6749(93)90085-T

Ortega, H. G., Liu, M. C., Pavord, I. D., Brusselle, G. G., FitzGerald, J. M., Chetta, A., et al. (2014). Mepolizumab treatment in patients with severe eosinophilic asthma. N. Engl. J. Med. 371, 1198-1207. doi: 10.1056/ NEJMoa1403290

Park, S. W., Kim, D., Chang, H. S., Park, S. J., Lee, Y. M., Park, J. S., et al. (2003). Association of interleukin-5 and eotaxin with acute exacerbation of asthma. Int. Arch. Allergy Immunol. 131, 283-290. doi: 10.1159/000072140

Pavord, I. D., Korn, S., Howarth, P., Bleecker, E. R., Buhl, R., Keene, O. N., et al. (2012). Mepolizumab for severe eosinophilic asthma (DREAM): a multicentre, double-blind, placebo-controlled trial. Lancet 380, 651-659. doi: 10.1016/S0140-6736(12)60988-X

Pazdrak, K., Olszewska-Pazdrak, B., Stafford, S., Garofalo, R. P., and Alam, R. (1998). Lyn, Jak2, and Raf-1 kinases are critical for the antiapoptotic effect of interleukin-5, whereas only Raf- 1 kinase is essential for eosinophil activation and degranulation. J. Exp. Med. 188, 421-429. doi: 10.1084/jem.188.3.421

Pazdrak, K., Stafford, S., and Alam, R. (1995). The activation of the Jak-STAT 1 signalling pathway by IL-5 in eosinophils. J. Immunol. 155, 397-402.

Pelaia, C., Busceti, M. T., Solinas, S., Terracciano, R., and Pelaia, G. (2018a), Real-life evaluation of the clinical, functional, and hematological effects of mepolizumab in patients with severe eosinophilic asthma: results of a singlecentre observational study. Pulm. Pharmacol. Ther. 53, 1-5. doi: 10.1016/j. pupt.2018.09.006

Pelaia, C., Busceti, M. T., Vatrella, A., Rago, G. F., Crimi, C., Terracciano, R., et al. (2019). Real-life rapidity of benralizumab effects in patients with severe allergic asthma: assessment of blood eosinophils, symptom control, lung function and oral corticosteroid intake after the first drug dose. Pulm. Pharmacol. Ther. 58:101830. doi: 10.1016/j.pupt.2019.101830 [Epub ahead of print].

Pelaia, C., Calabrese, C., Vatrella, A., Busceti, M. T., Garofalo, E., Lombardo, N., et al. (2018c). Benralizumab: from the basic mechanism of action to the potential use in the biological therapy of severe eosinophilic asthma. Biomed. Res. Int. 2018:4839230. doi: 10.1155/2018/4839230

Pelaia, G., Cuda, G., Vatrella, A., Gallelli, L., Caraglia, M., Marra, M., et al. (2005). Mitogen-activated protein kinases and asthma. J. Cell. Physiol. 202, 642-653. doi: 10.1002/jcp.20169

Pelaia, C., Vatrella, A., Bruni, A., Terracciano, R., and Pelaia, G. (2018b). Benralizumab in the treatment of severe asthma: design, development and potential place in therapy. Drug Des. Devel. Ther. 12, 619-628. doi: 10.2147/ DDDT.S155307

Pelaia, G., Vatrella, A., Busceti, M. T., Gallelli, L., Calabrese, C., Terracciano, R., et al. (2015). Cellular mechanisms underlying eosinophilic and neutrophilic airway inflammation in asthma. Mediat. Inflamm. 2015:879783. doi: $10.1155 / 2015 / 879783$

Pelaia, G., Vatrella, A., Busceti, M. T., Gallelli, L., Preianò, M., Lombardo, N., et al. (2016). Role of biologics in severe eosinophilic asthma: focus on reslizumab. Ther. Clin. Risk Manag. 12, 1075-1082. doi: 10.2147/TCRM. S111862

Pelaia, C., Vatrella, A., Busceti, M. T., Gallelli, L., Terracciano, R., Savino, R., et al. (2017). Severe eosinophilic asthma: from the pathogenic role of 
interleukin-5 to the therapeutic action of mepolizumab. Drug Des. Devel. Ther. 11, 3137-3144. doi: 10.2147/DDDT.S150656

Rossjohn, J., McKinstry, W. J., Woodcock, J. M., McClure, B. J., Hercus, T. R., Parker, M. W., et al. (2000). Structure of the activation domain of the GM-CSF/IL-3/IL-5 receptor common beta-chain bound to an antagonist. Blood 95, 2491-2498. doi: 10.1182/blood.V95.8.2491

Sakuishi, K., Oki, S., Araki, M., Porcelli, S. A., Miyake, S., and Yamamura, T. (2007). Invariant NKT cells biased for IL-5 production act as crucial regulators of inflammation. J. Immunol. 179, 3452-3462. doi: 10.4049/jimmunol.179.6.3452

Sano, M., Leff, A. R., Myou, S., Boetticher, E., Meliton, A. Y., Learoyd, J., et al. (2005). Regulation of interleukin-5-induced beta2-integrin adhesion of human eosinophils by phosphoinositide 3-kinase. Am. J. Respir. Cell Mol. Biol. 33, 65-70. doi: 10.1165/rcmb.2005-0076OC

Schleich, F., Brusselle, G., Louis, R., Vandenplas, O., Michils, A., Pilette, C., et al. (2014). Heterogeneity of phenotypes in severe asthma. The Belgian severe asthma registry (BSAR). Respir. Med. 108, 1723-1732. doi: 10.1016/j.rmed.2014.10.007

Schwartz, C., Willebrand, R., Huber, S., Rupec, R. A., Wu, D., Locksley, R., et al. (2015). Eosinophil-specific deletion of IKB $\alpha$ in mice reveals a critical role of NFKB-induced Bcl-xL for inhibition of apoptosis. Blood 125, 38963904. doi: 10.1182/blood-2014-10-607788

Shakoory, B., Fitzgerald, S. M., Lee, S. A., Chi, D. S., and Krishnaswamy, G. (2004). The role of human mast cell-derived cytokines in eosinophil biology. J. Interf. Cytokine Res. 24, 271-281. doi: 10.1089/107999004323065057

Shields, R. L., Lai, J., Keck, R., O'Connell, L. Y., Hong, K., Meng, Y. G., et al. (2002). Lack of fucose on human IgG1 N-linked oligosaccharide improves binding to Fcgamma RIII and antibody-dependent cellular toxicity. J. Biol. Chem. 277, 26733-26740. doi: 10.1074/jbc.M202069200

Siddiqui, S., Denlinger, L. C., Fowler, S. J., Akuthota, P., Shaw, D. E., Heaney, L. G., et al. (2019). Unmet needs in severe asthma subtyping and precision medicine trials. Bridging clinical and patient perspectives. Am. J. Respir. Crit. Care Med. 199, 823-829. doi: 10.1164/rccm.201809-1817PP

Smith, S. G., Chen, R., Kjarsgaard, M., Huang, C., Oliveria, J. P., O’Byrne, P. M., et al. (2016). Increased numbers of activated group 2 innate lymphoid cells in the airways of patients with severe asthma and persistent airway eosinophilia. J. Allergy Clin. Immunol. 137, 75-86. doi: 10.1016/j.jaci.2015.05.037

Stirling, R. G., van Rensen, E. I., Barnes, P. J., and Chung, K. F. (2001). Interleukin-5 induces $\mathrm{CD} 34+$ eosinophil progenitor mobilization and eosinophil CCR3 expression in asthma. Am. J. Respir. Crit. Care Med. 164, 1403-1409. doi: $10.1164 /$ ajrccm.164.8.2010002

Stout, B. A., Bates, M. E., Liu, L. Y., Farrington, N. N., and Bertics, P. J. (2004). IL-5 and granulocyte-macrophage colony-stimulating factor acyivate STAT3 and STAT5 and promote Pim-1 and cyclin D3 protein expression in human eosinophils. J. Immunol. 173, 6409-6417. doi: 10.4049/jimmunol.173.10.6409

Takatsu, K., and Nakajima, H. (2008). IL-5 and eosinophilia. Curr. Opin. Immunol. 20, 288-294. doi: 10.1016/j.coi.2008.04.001

Tanaka, H., Komai, M., and Nagao, K. (2004). Role of IL-5 and eosinophils in allergen-induced airway remodeling in mice. Am. J. Respir. Cell Mol. Biol. 31, 62-68. doi: 10.1165/rcmb.2003-0305OC

Thompson-Souza, G. A., Gropillo, I., and Neves, J. S. (2017). Cysteynil leukotrienes in eosinophil biology: functional roles and therapeutic perspectives in eosinophilic disorders. Front. Med. 4:106. doi: 10.3389/fmed.2017.00106

Uings, I., and McKinnon, M. (2002). Development of IL-5 receptor antagonists. Curr. Pharm. Des. 8, 1837-1844. doi: 10.2174/1381612023393800
Varricchi, G., Bagnasco, D., Borriello, F., Heffler, E., and Canonica, G. W. (2016). Interleukin-5 pathway inhibition in the treatment of eosinophilic respiratory disorders: evidence and unmet needs. Curr. Opin. Allergy Clin. Immunol. 16, 186-200. doi: 10.1097/ACI.0000000000000251

Varricchi, G., Bagnasco, D., Ferrando, M., Puggioni, F., Passalacqua, G., and Canonica, G. W. (2017a). Mepolizumab in the management of severe eosinophilic asthma in adults: current evidence and practical experience. Ther. Adv. Respir. Dis. 11, 40-45. doi: 10.1177/1753465816673303

Varricchi, G., and Canonica, G. W. (2016). The role of interleukin-5 in asthma. Expert. Rev. Clin. Immunol. 12, 903-905. doi: 10.1080/ 1744666X.2016.1208564

Varricchi, G., Senna, G., Loffredo, S., Bagnasco, D., Ferrando, M., and Canonica, G. W. (2017b). Reslizumab and eosinophilic asthma: one step closer to precision medicine? Front. Immunol. 8:242. doi: 10.3389/fimmu.2017.00242

Walker, J. A., Barlow, J. L., and McKenzie, A. M. (2013). Innate lymphoid cells: how did we miss them? Nat. Rev. Immunol. 13, 75-87. doi: 10.1038/ nri3349

Walsh, G. M. (2015). Mepolizumab-based therapy in asthma: an update. Curr. Opin. Allergy Clin. Immunol. 15, 392-396. doi: 10.1097/ACI.0000000000000183

Wood, L. J., Sehmi, R., Dorman, S., Hamid, Q., Tulic, M. K., Watson, R. M., et al. (2002). Allergen-induced increases in bone marrow $\mathrm{T}$ lymphocytes and interleukin-5 expression in subjects with asthma. Am. J. Respir. Crit. Care Med. 166, 883-889. doi: 10.1164/rccm.2108015

Woodruff, P. G., Modrek, B., Choy, D. F., Jia, G., Abbas, A. R., Ellwanger, A., et al. (2009). T-helper type 2-driven inflammation defines major subphenotypes of asthma. Am. J. Respir. Crit. Care Med. 180, 388-395. doi: 10.1164/ rccm.200903-0392OC

Xu, J., Jiang, F., Nayeri, F., and Zetterstrom, O. (2007). Apoptotic eosinophils in sputum from asthmatic patients correlate negatively with levels of IL-5 and eotaxin. Respir. Med. 101, 1447-1454. doi: 10.1016/j.rmed.2007.01.026

Yanagibashi, T., Satoh, T. M., Nagai, Y., Koike, M., and Takatsu, K. (2017). Allergic diseases: from bench to clinic - contribution of the discovery of IL-5. Cytokine 98, 59-70. doi: 10.1016/j.cyto.2016.11.011

Zhang, J., Kuvelkar, R., Murgolo, N. J., Taremi, S. S., Chou, C. C., Wang, P., et al. (1999). Mapping and characterization of the epitope(s) of Sch 55700, a humanized mAb, that inhibits human IL-5. Int. Immunol. 11, 1935-1944. doi: $10.1093 /$ intimm/11.12.1935

Zhang, X., Moilanen, C. E., and Kankaanranta, H. (2000). Enhancement of human eosinophil apoptosis by fluticasone propionate, budesonide, and beclomethasone. Eur. J. Pharmacol. 406, 325-332. doi: 10.1016/ S0014-2999(00)00690-7

Conflict of Interest: The authors declare that the research was conducted in the absence of any commercial or financial relationships that could be construed as a potential conflict of interest.

Copyright $\odot 2019$ Pelaia, Paoletti, Puggioni, Racca, Pelaia, Canonica and Heffler. This is an open-access article distributed under the terms of the Creative Commons Attribution License (CC BY). The use, distribution or reproduction in other forums is permitted, provided the original author(s) and the copyright owner(s) are credited and that the original publication in this journal is cited, in accordance with accepted academic practice. No use, distribution or reproduction is permitted which does not comply with these terms. 